\title{
Letter
}

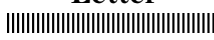

\section{Radioactive Contamination of a Pig Raised at a Farm within 20 km of the Fukushima Daiichi Nuclear Power Plant}

\author{
Kazutaka Yamada, Toshiro Yamaguchi* Kaita SaWAnO**, \\ Miori Kishimoto*** and Kazuhisa FurUhama**** \\ Obihiro University of Agriculture and Veterinary Medicine \\ Inada-cho, Obihiro-shi, Hokkaido 080-8555, Japan \\ *Gifu University, The United Graduate School of Veterinary Science \\ 1-1 Yanagido, Gifu-shi, Gifu Pref. 501-1193, Japan \\ **Fujifilm RI Pharma Co., Ltd. \\ 453-1, Shimo-okura, Matsuo-machi, Sammu-shi, Chiba Pref. 289-1592, Japan \\ *** Tokyo University of Agriculture and Technology \\ 3-5-8, Saiwai-cho, Fuchu-shi, Tokyo 183-8509, Japan \\ **** Iwate University \\ 3-18-8 Ueda, Morioka-shi, Iwate Pref. 020-8550, Japan
}

Received October 20, 2011

\begin{abstract}
A mixed breed pig that was raised at a farm within $20 \mathrm{~km}$ of the Fukushima Daiichi nuclear power plant on the day of the accident was moved to a clean area 17 days after the accident, slaughtered and sampled 41 days after arriving at the clean area. The $\gamma$-ray spectrum of belly, ham, loin, and heart were measured using $a \mathrm{Ge}$ semiconductor detector. Even though the animal had been kept in a clean area for 41 days, contamination with radioisotopic caesium was detected in pork. The pig had been kept inside a piggery and had been fed non-contaminated imported feed in both Fukushima and clean area of its all life. Broadcasts reported that feeding rice straw poses a risk of radioactive contamination of beef in Japan, but rice straw might not be the sole source of contamination. For the safety of future generations, it is necessary to monitor not only beef but also other animal products for food safety.
\end{abstract}

Key Words : caesium, food safety, Fukushima, pig, pork, radioactive contamination

The earthquake and subsequent tsunami on March 11, 2011 resulted in an accident at the Fukushima Daiichi nuclear power plant. Radioactive contamination of farm products became a serious problem. According to recent broadcasts and scientific studies, spinach ${ }^{1)}$, milk $^{2)}$, and fish ${ }^{3)}$ were affected; human health would also be affected because radioactive contamination in the food chain was an increasing concern, as it did as a result of the tests carried out at the Nevada Test Site in the $1950 \mathrm{~s}^{4)}$ and the nuclear accident at Chernobyl in 1986 ${ }^{5), 6)}$. To make matters worse, beef from Fukushima contaminated with radioactive caesium $(\mathrm{Cs})$ was sold to restaurants and consumers. It was said that beef cattle were contaminated after being fed rice straw stored outdoors even after the hydrogen explosions ${ }^{7)}$. Are beef cattle the only animals affected? Is contaminated rice straw the sole source of contamination? Therefore, Cs contamination should be examined not only in beef cattle but also in other livestock species to ensure food safety.

\section{Materials and Methods}

A mixed breed male pig, weighing around 
Table 1 Radioisotope Cs concentration in a pig* which was exposed within $20 \mathrm{~km}$ of the Fukushima Daiichi nuclear power plant

\begin{tabular}{|c|c|c|c|c|c|c|c|c|}
\hline & \multicolumn{4}{|c|}{${ }^{134} \mathrm{Cs}(0.605 \mathrm{MeV})$} & \multicolumn{4}{|c|}{${ }^{137} \mathrm{Cs}(0.662 \mathrm{MeV})$} \\
\hline & Belly & Ham & Loin & Heart & Belly & Ham & Loin & Heart \\
\hline Calculated value with physical half life** when the pig was slaughtered (10 May) & 58.9 & 59.6 & 64.3 & 31.8 & 70.7 & 68.9 & 79.6 & 41.1 \\
\hline Estimated value with effective half life ${ }^{* * *}$ when the pig was escaped to the clean area ( 29 March) & 157.7 & 159.6 & 172.2 & 85.2 & 182.8 & 178.1 & 205.8 & $\begin{array}{c}106.3 \\
(\mathrm{~Bq} / \mathrm{kg})\end{array}$ \\
\hline
\end{tabular}

*Exposure period: 17 days: clean period: 41 days

**Physical half life: ${ }^{134} \mathrm{Cs} 2$ years, ${ }^{137} \mathrm{Cs} 30$ years

$* * *$ Effective half life of pigs were calculated by biological half life: ${ }^{134} \mathrm{Cs} 29$ days, ${ }^{137} \mathrm{Cs} 30$ days

$100 \mathrm{~kg}$, that was raised at a farm within $20 \mathrm{~km}$ of the Fukushima Daiichi nuclear power plant on the day of the accident (March 12,2011) was moved to a clean area (i.e., an area not contaminated by radioactivity) $1000 \mathrm{~km}$ away 17 days after the accident (March 29, 2011), slaughtered 41 days after transfer to the clean area (May 10, 2011), and then sampled. This pig had been kept inside a piggery and fed non-contaminated imported feed, but no rice straw in both Fukushima and clean area of its all life. Another mixed breed male pig, weighing around $100 \mathrm{~kg}$, born and raised in a clean area, was also slaughtered on the same day and sampled as a control. The $\gamma$-ray spectrum $(0.05-1.5 \mathrm{MeV})$ of samples (100 g) from belly, ham, loin, heart, was measured with a Ge semiconductor detector (GMX-10180 ; Ortec, USA) for 12 hours. Radioactivity at the date of moving (29 March, 2011) were recalculated on basis of the respective isotope half-lives.

\section{Results}

Samples of belly, ham, loin, and heart were measured for 12 hours, and concentrations of ${ }^{134} \mathrm{Cs}(0.605 \mathrm{MeV})$ and ${ }^{137} \mathrm{Cs}(0.662 \mathrm{MeV})$ radioisotopes were calculated on basis of the respec- tive isotope half-lives (Table 1). No peaks were detected in any samples from the control pig. The radioactivities of these samples were lower than the provisional government standard values $(500 \mathrm{~Bq} / \mathrm{kg})$. Although the animal had been kept in a clean area for 41 days, contamination of edible meat with caesium radioisotopes was detected.

\section{Discussion}

The pig had been kept in a piggery within 20 $\mathrm{km}$ of the Fukushima Daiichi nuclear power plant, and had not been fed rice straw. Although broadcasts report that feeding rice straw poses a risk of radioactive contamination of beef in Japan, our results indicate that rice straw might not be the sole source of radioactive contamination. Intake of contaminated water or inhalation of contaminated air may also lead to radioactive contamination of livestock in that area. Wherever beef is available in Japan, we can trace its origin through individual identification numbers; however, such a traceability system is absent for pork. Therefore, we may have contaminated pork unknowingly.

In addition, humans lived in that area, who 

within $20 \mathrm{~km}$ of the Fukushima Daiichi nuclear power plant

do not eat rice straw, as well as pigs may be affected $^{8)}$. Thyroid cancer ${ }^{5)}$ and the onset of urinary bladder carcinogenesis ${ }^{6)}$ were reported after the Chernobyl accident. People who live near sites of nuclear accidents must, therefore, be monitored for a long period.

For the safety of future generations, it is necessary to continuously monitor not only beef but also other animal products for food safety.

\section{References}

1) Asahi. com. 2011., Radiation fears force farmers to Tokyo streets, Available at www. asahi. com/ english/TKY201104190225. html (Accessed 20 April 2011)

2) Hashimoto, K., Tanoi, K., Sakurai, K., Iimoto, T., Nogawa, N., Higaki, S., Kosaka, N., Takahashi, T., Enomoto, Y., Onoyama, I., Li, J. Y., Manabe, N., and Nakanishi, T., The radioactivity measurement of milk from the cow supplied with the meadow grass grown in Ibaraki-prefecture, after the nuclear power plant accident, RADIOISOTOPES, 60, 335-338(2011)
3) Asahi. com. 2011., Government sets iodine standards for seafood, Available at www. asahi. com/ english/TKY201104060124. html(Accessed 7 April, 2011)

4) McCarthy, M., Nuclear bomb test fallout may cause many US cancers, The Lancet, 350, 415 (1997)

5) Baverstock, K., Egloff, B., Pinchera, A., Ruchti, C. and Williams, D., Thyroid cancer after Chernobyl, Nature, 359, 21-22 (1992)

6) Romanenko, A., Kakehayashi, A., Morimura, K., Wanibuchi, H., Wei, M., Vozianov, A. and Fukushima, S., Urinary bladder carcinogenesis induced by chronic exposure to persistent lowdose ionizing radiation after Chernobyl accident, Carcinogenesis, 30, 1821-1831 (2009)

7) Asahi. com. 2011., Beef contaminated with Cesium sold at market, Available at www. asahi. com/english/TKY201107120464. html (Accessed 13 July, 2011)

8) Asahi. com. 2011., Radioactive iodine turns up in 7 breast milk samples, Available at www. asahi. com/english/TKY201105020109.html (Accessed 3 May, 2011) 


\title{
福島第一原子力発電所 $20 \mathrm{~km}$ 圏内で飼育されていた豚の放射能污染例
}

\author{
山田一孝, 山口敏朗 ${ }^{*}$, 澤野海太 ${ }^{* *}$, 岸本海織 ${ }^{* * *}$, 古濱和久 $* * * *$ \\ 带広畜産大学 \\ 080-8555 北海道带広市稲田町 \\ *岐皁大学大学院連合獣医学研究科 \\ 501-1193＼cjkstart岐阜県岐阜市柳戸 1-1 \\ **富士フイルム RI ファーマ株式会社 \\ 289-1592 千葉県山武市松尾町下大藏 453-1 \\ ***東京農工大学 \\ 183-8509＼cjkstart東京都府中市幸町 3-5-8 \\ ****岩手大学 \\ 020-8550＼cjkstart岩手県盛岡市上田 3-18-8
}

福島第一原子力発電所から $20 \mathrm{~km}$ 圈内で飼育されていた交雑種豚が，事故 17 日後に清浄区域へ 移動し, 移動 41 日後に試料が採材された。Ge 半導体検出器を用いて，バラ，モモ，ロース及び心 臓の $\gamma$ 線スペクトルを測定したところ，放射性セシウムの存在が確認された。被検豚は移動前後 ともに豚舎で飼育され，生涯污染のない輸入飼料で飼養されていた。牛肉の放射能污染の原因は污 染された稲藻と報道されているが, 稲藻だけが污染の原因ではない可能性がある。次世代のために, 食の安全の観点から牛肉のみならず他の畜産物についても監視が必要である。 